\title{
A Study on the Color of Natural Solvent for the Red Color Reproduction of Safflower
}

\author{
Mi Young Lee ${ }^{1}$, Koang Chul $\mathrm{Wi}^{2^{*}}$ \\ ${ }^{1}$ Hanseo University Museum, Hanseo University, Seosan 31962, Korea \\ ${ }^{2}$ Department of Cultural Heritage Conservation, Hanseo University, Seosan 31962, Korea
}

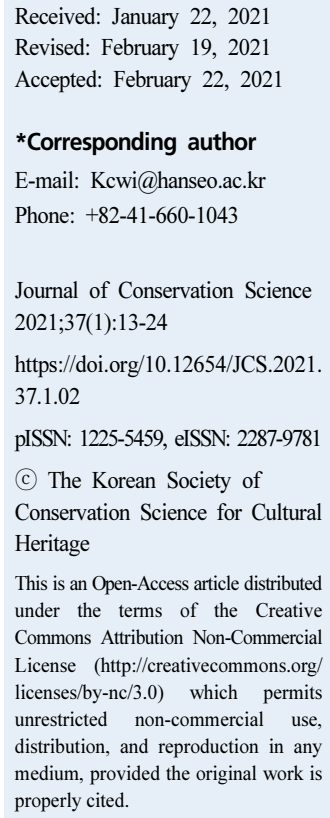

ABSTRACT Safflower, a natural dye representing red, is the dye that materials and dyeing method are recorded in the literature, including materials and dyeing. Although the safflower is the same, the ash used as a mordant is recorded differently in each literature, which greatly affects the aesthetic perspective in realizing the traditional safflower red. Therefore, the optimal conditions for realizing the traditional safflower red were sought. The experiment was conducted by $\mathrm{pH}$ investigation, dyeing and color analysis by dyeing solution water, concentration, and temperature by ash, and the unique color of red was confirmed. As a result of the test, the $\mathrm{pH}$ point of time when the unique color was expressed was 11.53 as goosefoot ash (natural bedrock water), which was $1: 100$ for concentration and $70^{\circ} \mathrm{C}$ for temperature, which was easier to extract red pigment than other ash, indicating that it is suitable for safflower dyeing. The analysis of the ash showed that $\mathrm{K}$ and $\mathrm{Si}$ play an important role in dyeing, especially $\mathrm{Si}$, which is an element that inhibits carthamon. The color of red was similar to that of KS Standard vivid purplish red in the ash of the goosefoot, and the other ash was deep purplish pink. In the light of findings, it was possible to quantify the dyeing method through traditional materials and find the standard color of red color, and it is judged to be a basic data for studying the unique color of natural materials.

Key Words Goosefoot, Bean pod, Rice straw, Safflower, Ash, Safflower color, Natural dye, Mordant

\section{INTRODUCTION}

The color using safflower is generally named as a safflower color, which is called reddish color that is brighter and pinkish as compared to red. As a polychromatic dye that includes 2 different pigments, safflower color can show a subtle color. While carthamon of safflower is dyed on protein fabrics only, carthamin responds to and is dyed on both protein and cellulose fabrics, so fabrics that can be dyed differ by pigment. As for silk fabrics, carthamon and carthamin are mixed, creating a bright and reddish color, whereas only carthamin of safflower can be seen in case of dyeing cotton fabrics.
The method for realizing the traditional safflower red is to extract carthamin using alkaline solvent, which is a red dye that information of ash materials is recorded in the literature. Literature that recorded detailed description of safflower and ash materials include ${ }^{『}$ Ojuyeonmunjangjeonsango $₫$, ${ }^{『}$ Gyuhapchongseo $\_,{ }^{『}$ Imwongyeongjeji $₫,{ }^{『}$ Sangbangjeongrye $\_$ and ${ }^{『}$ Bonchogangmok $\_$which were written in the Joseon Dynasty. Goosefoot is recorded in ${ }^{『}$ Sangbangjeongrye $₫$, bean pod in ${ }^{『}$ Ojuyeonmunjangjeonsango $₫,{ }^{『}$ Gyuhapchongseo $\_$and ${ }^{『}$ Imwongyeongjeji』, and rice straw is recorded in ${ }^{\circledR}$ Cheongonggaemul $』$ respectively. Although safflower, ash, dyeing recorded in the ancient literatures are considered important as data for the process of realizing unique 
safflower color, they turned out to have a problem.

First, types of ash materials differed by literatures. Each ash material has a different ingredient, which makes difference in changes of color, but data that compares by dyeing with ash materials under the same condition is necessary to understand such difference. However, difference by ash materials has not been mentioned. Second, there exists no data that defined color names based on the difference of the color of safflower. Various names specified in the ancient literatures classified by the names of color such as Daehong (deep reddish color), Dahong (crimson red), Simhong (deep red) and Jinhong (dark red), but it is unable to estimate how much each color differs. Therefore, it is impossible to compare with crimson red to dark pink that are the present colors of safflower.

Problems mentioned above were also pointed out and in spite of efforts for expressing carthamin through reproduction of traditional dyeing, aesthetic perspectives played a big part overall (Kim, 2010). And it is difficult to realize standard color of safflower through the method and traditional dyeing method recorded in the ancient literature due to the difference in interpretation of researchers (Nam et al., 1995; Chu and Nam, 1997). Most of existing studies classified as traditional dyeing method and dyeing method that improved the former (Kiyoshi, 1973; Tamako and Mitsuhiko, 2007), and because most of which focused on the researches of color comparison of chemicals rather than on traditional materials (Park and Hong, 2002; Son et al., 2008), studies on the unique color of safflower by natural ash materials still remain insufficient.

The purpose of this study is to realize traditional safflower color using safflower out of red dyes. First of all, this study aims to standardize color names of safflower-dyed fabrics by natural ash materials by quantifying dyeing method of each ash material recorded in the literature. This study also intends to expand colors falling under the purview of safflower color of safflower through understanding of physicochemical characteristics and sharpness of color by safflower ash materials by comparing them with ash materials shown in the literature after dyeing ashes not suggested in the literature.

\section{TEST AND METHOD}

\subsection{Test specimen}

\subsubsection{Safflower and fabric}

As for safflower dye, this study purchased materials cultivated and dried around August 2018 in the province of Haenam with cellulose cotton cloth dyed only with safflower color. Density of cotton cloth was about $41 \times 41$ inch $^{2}$ and thickness was $0.52 \mathrm{~mm}$, and the unit of thickness of fabric is $270 \mathrm{~g} / \mathrm{m}^{2}$, and the weight of fabric specimen to be used for dyeing was $0.5 \mathrm{~g}$.

\subsubsection{Ash materials and dyeing solution water}

Materials for alkaline solvent were the ones cultivated in 2018, and this study purchased goosefoot in Namwon, Jeollabuk-do, bean pod in Chuncheon, Gangwon-do and rice straw in Yesan, Chungcheongnam-do respectively. Goosefoot, bean pod, rice straw were the ones incompletely combusted (Kiyoshi, 1973). $5 \mathrm{~kg}$ of goosefoot and bean pod were reduced to $960 \mathrm{~g}$ and $970 \mathrm{~g}$ of ash materials respectively, and $10 \mathrm{~kg}$ of rice straw left $950 \mathrm{~g}$ of ash materials.

As for dyeing solution water used for manufacturing alkaline solvent, this study used both natural bedrock water and deionized water, and mineral content of natural bedrock water includes $\mathrm{mg} / \mathrm{L}$ - Calcium (32.5 44.9), Sodium (10.5 10.9), Potassium (1.0 1.7), Magnesium $(3.8 \sim 6.0)$ and Fluorine $(0.5 \sim 0.9)$. Deionized water is a generally-used solution, which was purified through a pure water manufacturing equipment (Pure RO, Romax, Human Science, KOR).

\subsubsection{Acid solution}

As for rice vinegar which is an acid solution, this study used one that contains purified water, rice-extracted concentrate $18.28 \%$, saccharized brown rice concentrate $4.57 \%$ etc (Lee and $\mathrm{Wi}, 2019)$

\subsection{Test method}

\subsubsection{Manufacturing of lye}

Using both natural bedrock water and deionized water as dyeing solution water, this study set concentration of each lye to $1: 10,1: 50$ and $1: 100$ according to the weight $(w t \%)$ of ash and conducted test by differentiating 
temperature of water as $50^{\circ} \mathrm{C}, 60^{\circ} \mathrm{C}, 70^{\circ} \mathrm{C}, 80^{\circ} \mathrm{C}, 90^{\circ} \mathrm{C}$ and $100^{\circ} \mathrm{C}$. After putting dyeing solution water by temperature and concentration and leaving lye at room temperature for about an hour to use supernatant after depositing for two days while maintaining temperature of $11 \sim 15^{\circ} \mathrm{C}$. Aftr that, this study manufactured clear ash solvent after filtering lye using filter paper (No. 6, ADVANTEC ${ }^{\circledR}$, Toyo Roshi, Ltd., JPN). Upon completion of the foregoing, this study measured $\mathrm{pH}$ (pHTestr 30, EUTECH, SGP) at intervals of $24 \mathrm{~h}$ and $48 \mathrm{~h}$ by dyeing solution water, concentration and temperature, and calculated average value excepting maximum and minimum values (Lee, 2020).

\subsubsection{Extraction of dye and dyeing}

Safflower is a polychromatic dye containing both carthamon and carthamin, so this study extracted carthamin after removing carthamon. For removal of carthamon, this study deposited safflower $100 \mathrm{~g}$ which is dried for 2 days in the water (deionized water, $5 \mathrm{~L}$ ) and repeated work adding physical force from day 3 7 until clear water comes out. After removing carthamon, this study removed moisture of safflower completely by using a dehydrator for 5 minutes. To extract carthamin from dehydrated safflower, this study put safflower into $50 \mathrm{~mL}$ lye of $2 \%$ concentration which was filtered at room temperature of $25^{\circ} \mathrm{C}$ and separated damaged leaves using stainless filter after soaking about an hour (Lee and $\mathrm{Wi}, 2019$ ).

To dye with carthamin-extracted solution, this study adjusted $\mathrm{pH}$ to $6.77 \pm 6.90$ (Tamako and Mitsuhiko, 2007) using rice vinegar with $8 \%$ of acidity, and dyed for 24 hours at $25^{\circ} \mathrm{C}$ with the ratio of dyeing solution at $1: 50$. For dyed specimen, this study washed with natural bedrock water and deionized water that were used as dyeing solution water, and dried naturally after 3 times of dyeing.

\subsection{Element analysis of lye}

To identify ion content and element included in lye, this study measured using an Inductively Coupled Plasma-Mass Spectrometer (ELAN DRC-e ICP-MS, PerklnElmer SCIEX, USA). As for analysis method, this study used 8 kinds of lye in total including 3 kinds of ash materials and 2 kinds of dyeing solution water, and for specimen, this study established solution manufactured at the ratio of $1: 100$ as a standard, and measured by diluting 10 times, 500 times and 1,000 times respectively by concentration.

\subsection{Color analysis of safflower dyeing}

This study analyzed colors of fabrics dyed with lye manufactured by ash materials and this study found values of $\mathrm{L} \mathrm{a}^{*} \mathrm{~b}^{*}$ under the measurement conditions of Observer $10^{\circ}$ and UV 100\% with a Single Primary D 65 light source. The test adopted a method that displays color difference in accordance with $\mathrm{L}^{*} \mathrm{a}^{*} \mathrm{~b}^{*}$ Color System of Commission Internationale de l'Eclairage (CIE) which is equivalent to the regulations of KS A 0066 by applying $\mathrm{L}^{*} \mathrm{a}^{*} \mathrm{~b}^{*}$ Color System of CIE. Basically, L ${ }^{*}{ }^{*} b^{*}$ Color System evaluates and calculates values of color difference based on the three basic concepts of lightness, hue and chroma, but $\mathrm{L}^{*}$ value is the one that digitized difference of lightness, and this study used by displaying from 0 to 100 .

On the plain coordinate system like $\mathrm{XY}$ coordinate system, the closer the values of $a^{*} b^{*}$ fall to 0 , it means a color with lower chroma and if the value gets bigger it represents a color with high chroma, and $\mathrm{a}^{*}$ and $\mathrm{b}^{*}$ are the ones that digitize red and blue, and this study compared difference of color from the term 1 to 3 for examining color change by dyeing by ash materials, temperature, concentration and dyeing water.

For analysis, this study measured color difference by applying 2 different methods using spectrophotometer (CM-2600d, KONICA-MINOLTA, JPN) and image processing software (PicMan, WaferMasters, Inc., CA, USA). As the scope of color difference in safflower through natural alkaline solvent was not so wide, this study aimed to examine data of standardized color.

As for the method of measurement, this study used average value after measuring by repeating spectrophotometer 5 times, and measured color difference using image processing software after constructing an image using Color Scanner (Document Centre C 360, FUJI XEROX, JPN) for the same quantity of light.

For analyzed data, this study conducted a comparative analysis using Figure 1. after substituting KS A 0062 Display Method by Three Attributes of Color, KS A 0011 Name of Object Colours and Munsell Color System for numerical value of $\mathrm{L}^{*} \mathrm{a}^{*} \mathrm{~b}^{*}$ in the CIE Color System. 


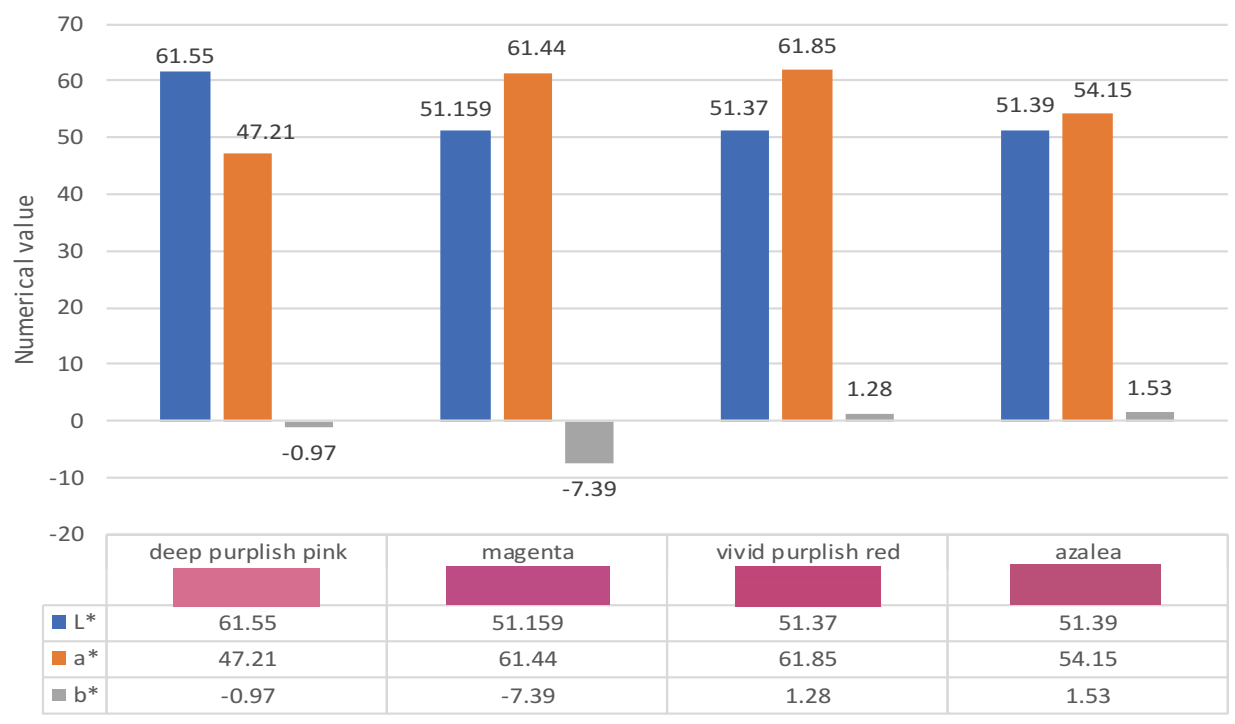

Figure 1. The numerical range of safflower color.

\section{RESULT AND CONSIDERATION}

\subsection{Analysis of ingredients}

\subsubsection{Investigation of $\mathrm{pH}$ by ash materials}

Table 1 shows the result of investigation of $\mathrm{pH}$ and comparison by temperature according to the ratio of ash materials. As for $\mathrm{pH}$ value by ash solvent, goosefoot ash material is maintaining $\mathrm{pH} 11.52 \sim 12.54$, and bean pod and rice straw were measured to be $\mathrm{pH} 12.13 \sim 13.44$ and $\mathrm{pH}$ $10.44 \sim 11.51$ respectively. $\mathrm{pH}$ value of all ash materials ranged from $\mathrm{pH} 10$ to 13 , showing strong alkali properties. $\mathrm{pH}$ of ash materials was in the range of $\mathrm{pH} 11.5$ which is the standard of alkali solution for chemicals used when extracting carthamin from safflower in the advanced studies. Ash material with $\mathrm{pH} 11.5$ was measured in 2 goosefoot ash and 1 rice straw ash.

Goosefoot ash material was shown at $1: 100,70^{\circ} \mathrm{C}, \mathrm{pH}$ 11.53 , natural bedrock water and $1: 100,100^{\circ} \mathrm{C}, \mathrm{pH} 11.52$, deionized water and rice straw was shown at $1: 10,90^{\circ} \mathrm{C}$ $\mathrm{pH} 11.51$ (deionized water), but considering the value of $\mathrm{a}^{*}$ red, $\mathrm{pH} 11.53$ of goosefoot ash material and the value of $\mathrm{a}^{*}$ red are 1.24 12.31 higher, so they are considered ash materials that dyeing of carthamin is easier than other ash materials. It is also considered that color was expressed clearly as mineral ions of natural bedrock water affected extraction of carthamin and dyeing.
Although rice straw ash material was shown at $1: 10$, $90^{\circ} \mathrm{C} \mathrm{pH} 11.51$ (deionized water), the point where rice straw was the highest in color difference was $1: 50,60^{\circ} \mathrm{C} \mathrm{pH} 10.98$ (natural bedrock water) and $1: 50,100^{\circ} \mathrm{C} \mathrm{pH} 11.39$ (deionized water), indicating that there exist respective $\mathrm{pH}$ condition for each ash material. And bean pod ash is higher by 2 as compared to $\mathrm{pH} 11$ showing strong alkaline properties, so it is considered unstable for dyeing of carthamin.

\subsubsection{Analysis of metal ingredients of lye}

Table 2 and Figure 2 show the result of analysis on the 3 kinds of lye. Detected elements include $\mathrm{Al}, \mathrm{Mg}, \mathrm{Na}, \mathrm{Fe}$, $\mathrm{P}, \mathrm{Ca}, \mathrm{K}, \mathrm{Si}$ etc., and $\mathrm{K}$ was contained the most among all ingredients detected, and as for goosefoot lye, high value of $18 \%$ was detected in 2 points of dyeing solution water. In regards to $\mathrm{Si}$, rice straw lye differed from other solvents about $4 \sim 8$ times in both dyeing solution water, showing properties that prevents dyeing of carthamon (Kiyoshi, 1973).

It is estimated that it was easy to extract carthamin as $\mathrm{Si}$ prevents most of yellow dye when dyeing safflower with rice straw lye, and $\mathrm{Ca}$ was also detected twice as much as bean pod, and as rice straw ash material was measured as value which is similar to magenta $\left(\mathrm{L}^{*} 51.159, \mathrm{a}^{*} 61.44, \mathrm{~b}^{*}-7.39\right)$ color that moved to the direction of red about $\mathrm{a}^{*} 10$ than bean pod ash which was measured as a color similar to deep purplish pink $\left(\mathrm{L}^{*} 61.55, \mathrm{a}^{*} 47.21, \mathrm{~b}^{*}-0.97\right)$ and heightened dyeing. 
Table 1. Result of $\mathrm{pH}$ of ash solvent

\begin{tabular}{|c|c|c|c|c|c|c|c|c|c|}
\hline \multirow{2}{*}{$\begin{array}{l}\text { Ratio } \\
(w t \%)\end{array}$} & \multirow{2}{*}{ Ash } & \multirow{2}{*}{$\begin{array}{c}\text { Solution } \\
\text { water }\end{array}$} & \multirow{2}{*}{ Day } & \multicolumn{6}{|c|}{ Temperature pH } \\
\hline & & & & $50{ }^{\circ} \mathrm{C}$ & $60^{\circ} \mathrm{C}$ & $70^{\circ} \mathrm{C}$ & $80^{\circ} \mathrm{C}$ & $90^{\circ} \mathrm{C}$ & $100^{\circ} \mathrm{C}$ \\
\hline \multirow{12}{*}{$1: 10$} & \multirow{4}{*}{ Goosefoot } & \multirow{2}{*}{ N.B.W } & 1 & 12.25 & 12.34 & 12.33 & 12.43 & 12.28 & 12.41 \\
\hline & & & 2 & 12.30 & 12.39 & 12.33 & 12.49 & 12.32 & 12.52 \\
\hline & & \multirow{2}{*}{ D.W } & 1 & 12.48 & 12.39 & 12.43 & 12.39 & 12.46 & 12.41 \\
\hline & & & 2 & 12.54 & 12.35 & 12.48 & 12.39 & 12.47 & 12.49 \\
\hline & \multirow{4}{*}{ Bean pod } & \multirow{2}{*}{ N.B.W } & 1 & 13.03 & 13.18 & 13.26 & 13.32 & 13.32 & 13.29 \\
\hline & & & 2 & 13.15 & 13.13 & 13.31 & 13.28 & 13.25 & 13.18 \\
\hline & & \multirow{2}{*}{ D.W } & 1 & 13.33 & 13.34 & 13.28 & 13.44 & 13.38 & 13.32 \\
\hline & & & 2 & 13.44 & 13.29 & 13.19 & 13.40 & 13.36 & 13.39 \\
\hline & \multirow{4}{*}{$\begin{array}{l}\text { Rice } \\
\text { straw }\end{array}$} & \multirow{2}{*}{ N.B.W } & 1 & 10.86 & 10.76 & 10.74 & 10.94 & 10.99 & 11.06 \\
\hline & & & 2 & 10.75 & 10.73 & 10.79 & 10.78 & 10.80 & 11.02 \\
\hline & & \multirow{2}{*}{ D.W } & 1 & 11.38 & 11.02 & 11.29 & 11.37 & 11.44 & 11.30 \\
\hline & & & 2 & 11.37 & 11.13 & 11.43 & 11.34 & 11.51 & 11.36 \\
\hline \multirow{12}{*}{$1: 50$} & \multirow{4}{*}{ Goosefoot } & \multirow{2}{*}{ N.B.W } & 1 & 12.11 & 12.33 & 12.31 & 12.30 & 12.07 & 12.06 \\
\hline & & & 2 & 12.23 & 12.16 & 12.22 & 12.32 & 12.13 & 12.04 \\
\hline & & \multirow{2}{*}{ D.W } & 1 & 12.12 & 12.26 & 12.25 & 12.31 & 12.32 & 12.04 \\
\hline & & & 2 & 12.24 & 12.25 & 12.26 & 12.26 & 12.26 & 11.99 \\
\hline & & \multirow{2}{*}{ N.B.W } & 1 & 13.91 & 13.03 & 13.19 & 13.18 & 13.14 & 13.20 \\
\hline & Bean nod & & 2 & 12.82 & 13.11 & 13.05 & 13.08 & 13.22 & 13.18 \\
\hline & Dean pou & \multirow{2}{*}{ D.W } & 1 & 13.12 & 13.40 & 13.15 & 13.24 & 13.25 & 13.24 \\
\hline & & & 2 & 13.05 & 13.20 & 13.16 & 13.27 & 13.22 & 13.22 \\
\hline & \multirow{4}{*}{$\begin{array}{l}\text { Rice } \\
\text { straw }\end{array}$} & \multirow{2}{*}{ N.B.W } & 1 & 10.78 & 10.59 & 10.73 & 11.04 & 10.86 & 10.91 \\
\hline & & & 2 & 10.77 & 10.98 & 10.82 & 10.93 & 10.82 & 10.92 \\
\hline & & \multirow{2}{*}{ D.W } & 1 & 11.04 & 11.14 & 10.98 & 11.27 & 11.04 & 11.11 \\
\hline & & & 2 & 11.16 & 11.25 & 11.25 & 11.38 & 11.31 & 11.39 \\
\hline \multirow{12}{*}{$1: 100$} & & N B W & 1 & 11.75 & 11.77 & 11.61 & 11.96 & 11.82 & 11.69 \\
\hline & Geosefont & N.B.W & 2 & 11.65 & 11.65 & 11.53 & 11.83 & 11.65 & 11.85 \\
\hline & Goosetoot & D W & 1 & 11.75 & 11.89 & 11.94 & 11.92 & 11.86 & 11.64 \\
\hline & & D.w & 2 & 11.75 & 11.76 & 11.87 & 11.85 & 11.77 & 11.52 \\
\hline & & NBW & 1 & 12.42 & 12.36 & 12.26 & 12.36 & 12.28 & 12.47 \\
\hline & & IV.D. W & 2 & 12.40 & 12.13 & 12.14 & 12.21 & 12.45 & 12.44 \\
\hline & Bean pod & W & 1 & 12.60 & 12.45 & 12.40 & 12.58 & 12.55 & 12.59 \\
\hline & & D.w & 2 & 12.59 & 12.41 & 12.22 & 12.64 & 12.67 & 12.58 \\
\hline & & NB W & 1 & 10.49 & 10.44 & 10.36 & 10.34 & 10.46 & 10.54 \\
\hline & Rice & N.B.W & 2 & 10.43 & 10.29 & 10.38 & 10.45 & 10.48 & 10.59 \\
\hline & straw & & 1 & 10.76 & 10.96 & 10.81 & 11.02 & 10.92 & 10.81 \\
\hline & & D.W & 2 & 10.93 & 11.01 & 10.95 & 10.98 & 11.17 & 10.92 \\
\hline
\end{tabular}

N.B.W, natural bedrock water; D.W, deionized water 
Table 2. Result of ICP-MS analysis of ash solvent

\begin{tabular}{|c|c|c|c|c|c|c|c|c|c|c|}
\hline \multirow{2}{*}{ No. } & \multirow{2}{*}{$\begin{array}{l}\text { Ratio } \\
\text { wt } \%\end{array}$} & \multirow{2}{*}{$\begin{array}{l}\text { Solution } \\
\text { name }\end{array}$} & \multicolumn{8}{|c|}{ Elements (ppm) } \\
\hline & & & Al & Mg & $\mathbf{N a}$ & $\mathrm{Fe}$ & $\mathbf{P}$ & $\mathbf{C a}$ & $\mathbf{K}$ & $\mathbf{S i}$ \\
\hline 1 & \multirow{6}{*}{$\begin{array}{c}1 \\
: \\
100\end{array}$} & $\begin{array}{l}\text { Goosefoot } \\
\text { (N.B.W) }\end{array}$ & 67 & 775 & 1247 & 5 & 379 & 578 & 181880 & 1207 \\
\hline 2 & & $\begin{array}{l}\text { Goosefoot } \\
\text { (D.W) }\end{array}$ & 5 & 372 & 497 & 3 & 571 & 335 & 183017 & 202 \\
\hline 3 & & $\begin{array}{l}\text { Bean pod } \\
(\text { (N.B.W) }\end{array}$ & 4.7 & 477 & 1548 & 4 & 2585 & 205 & 96193 & 1792 \\
\hline 4 & & $\begin{array}{l}\text { Bean pod } \\
\text { (D.W) }\end{array}$ & 16.8 & 374 & 967 & 3 & 3190 & 208.9 & 104158 & 1074 \\
\hline 5 & & $\begin{array}{l}\text { Rice straw } \\
\text { (N.B.W) }\end{array}$ & 0.6 & 243 & 1823 & 5 & 664 & 411 & 65327 & 7888 \\
\hline 6 & & $\begin{array}{l}\text { Rice straw } \\
\text { (D.W) }\end{array}$ & 2 & 86303 & 1158 & 10 & 1048 & 373 & 53812 & 8030 \\
\hline
\end{tabular}

ICP-MS, Inductively Coupled Plasma-Mass Spectrometer; N.B.W, natural bedrock water; D.W, deionized water

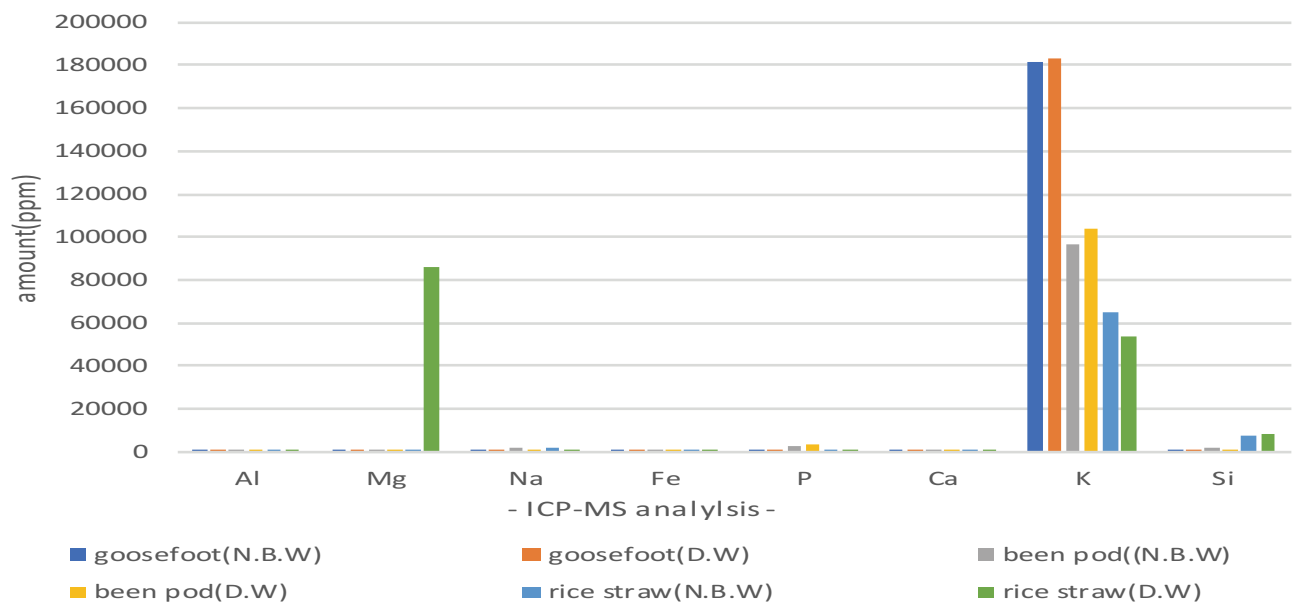

Figure 2. Result of ICP-MS analysis graph for ash solvent. ICP-MS, Inductively Coupled Plasma-Mass Spectrometer; N.B.W, natural bedrock water; D.W, deionized water.

\subsection{Color analysis}

\subsubsection{Result of spectrophotometer}

This study compared average value of lightness $\left(\mathrm{L}^{*}\right)$ and chromaticness indices $\left(a^{*}, b^{*}\right)$ generated as a result of color difference analysis on the $1^{\text {st }} \sim 3^{\text {rd }}$ dyed fabrics by ash materials with KS Standard colors, and shown color change in the Table 3.

Goosefoot ash material is in the range of color value similar to azalea $\left(\mathrm{L}^{*} 51.39, \mathrm{a}^{*} 54.15, \mathrm{~b}^{*} 1.53\right)$, and the value of color difference of 2 kinds of dyeing solution water showed a difference from the KS Standard color. With numerical values of $\mathrm{L}^{*} 55.65, \mathrm{a}^{*} 48.71$ and $\mathrm{b}^{*}-2.48$, natural bedrock water $\left(1: 100,70^{\circ} \mathrm{C}, \mathrm{pH} 11.53\right)$ differed from azalea by $\mathrm{L}^{*} 4.26, \mathrm{a}^{*}-5.44, \mathrm{~b}^{*}-4.01$, and it became brighter as lightness, the value of $\mathrm{L}^{*}$ increased, but became murky with decrease in red of $a^{*}$ and increase in blue of $b^{*}$. With numerical values of $\mathrm{L}^{*} 51.50, \mathrm{a}^{*} 49.90$ and $\mathrm{b}^{*} 2.33$, deionized water $\left(1: 100,70^{\circ} \mathrm{C}, \mathrm{pH} 11.87\right)$ also differed by $\mathrm{L}^{*} 0.11$, $a^{*}-4.25$ and $b^{*} 0.80$ as compared to azalea color, but the difference in value of lightness, the value of $\mathrm{L}^{*}$ was insignificant, and sharpness lowered as red decreased in $\mathrm{a}^{*}$ value and yellow increased in $b^{*}$ value of chroma. 2 kinds of dyeing solution water became murky as sharpness lowered, 
Table 3. Comparison of $\mathrm{L}^{*} \mathrm{a}^{*} \mathrm{~b}^{*}$ values according to the ash component KS standard (Spectrophotometer)

\begin{tabular}{|c|c|c|c|c|c|c|c|c|c|c|c|}
\hline \multirow{2}{*}{ No } & \multirow{2}{*}{ Ash } & \multirow{2}{*}{ Count } & \multicolumn{3}{|c|}{ Bedrock water } & \multicolumn{3}{|c|}{ Deionized water } & \multirow{2}{*}{\multicolumn{2}{|c|}{$\begin{array}{l}\text { KS standard } \\
\text { Color value } \\
\end{array}$}} & \multirow{2}{*}{$\mathbf{C N}$} \\
\hline & & & \multicolumn{2}{|c|}{ Color value } & Color & \multicolumn{2}{|c|}{ Color value } & \multirow[t]{2}{*}{ Color } & & & \\
\hline \multirow{11}{*}{1} & \multirow{9}{*}{$\begin{array}{l}\text { Goose } \\
\text { foot }\end{array}$} & \multirow{3}{*}{1} & $\mathbf{L}^{*}$ & 58.26 & & $\mathbf{L}^{*}$ & 51.78 & & \multirow{2}{*}{$\mathbf{L}^{*}$} & \multirow{2}{*}{51.39} & \\
\hline & & & $a^{*}$ & 48.45 & & $a^{*}$ & 51.04 & & & & \\
\hline & & & $\mathbf{b}^{*}$ & -2.68 & & $\mathbf{b}^{*}$ & 0.03 & & \multirow{3}{*}{$a^{*}$} & \multirow{3}{*}{54.15} & \\
\hline & & \multirow{3}{*}{2} & $\mathbf{L}^{*}$ & 55.95 & & $\mathbf{L}^{*}$ & 50.24 & & & & a \\
\hline & & & $a^{*}$ & 48.07 & & $a^{*}$ & 48.82 & & & & $\mathrm{z}$ \\
\hline & & & $\mathbf{b}^{*}$ & -1.44 & & $\mathbf{b}^{*}$ & 2.25 & & & & a \\
\hline & & & $\mathbf{L}^{*}$ & 52.75 & & $\mathbf{L}^{*}$ & 52.48 & & $\mathbf{b}^{*}$ & 1.53 & e \\
\hline & & 3 & $a^{*}$ & 49.62 & & $a^{*}$ & 49.83 & & & & $\mathrm{a}$ \\
\hline & & & $\mathbf{b}^{*}$ & -3.32 & & $\mathbf{b}^{*}$ & 4.70 & & & & \\
\hline & & & $\mathbf{L}^{*}$ & $a^{*}$ & $\mathbf{b}^{*}$ & $\mathbf{L}^{*}$ & $a^{*}$ & $\mathbf{b}^{*}$ & & & \\
\hline & Av & & 55.65 & 48.71 & -2.48 & 51.50 & 49.90 & 2.33 & & & \\
\hline & & & $\mathbf{L}^{*}$ & 65.59 & & $\mathbf{L}^{*}$ & 65.13 & & & & \\
\hline & & 1 & $a^{*}$ & 37.14 & & $a^{*}$ & 39.23 & & $\mathbf{L}$ & 61.55 & \\
\hline & & & $\mathbf{b}^{*}$ & 3.89 & & $\mathbf{b}^{*}$ & 3.52 & & & & \\
\hline & & & $\mathbf{L}^{*}$ & 61.78 & & $\mathbf{L}^{*}$ & 62.80 & & $a^{*}$ & 47.21 & \\
\hline & $\begin{array}{c}\text { Bean } \\
\text { pod }\end{array}$ & 2 & $a^{*}$ & 40.87 & & $\mathbf{a}^{*}$ & 39.69 & & & & d. \\
\hline 2 & & & $\mathbf{b}^{*}$ & 1.90 & & $\mathbf{b}^{*}$ & 4.87 & & * & & p. \\
\hline & & & $\mathbf{L}^{*}$ & 58.79 & & $\mathbf{L}^{*}$ & 59.82 & & D & -0.91 & p. \\
\hline & & 3 & $a^{*}$ & 41.96 & & $a^{*}$ & 41.89 & & & & \\
\hline & & & $\mathbf{b}^{*}$ & 3.76 & & $\mathbf{b}^{*}$ & 3.32 & & & & \\
\hline & $A_{V}$ & & $\mathbf{L}^{*}$ & $a^{*}$ & $\mathbf{b}^{*}$ & $\mathbf{L}^{*}$ & $a^{*}$ & $\mathbf{b}^{*}$ & & & \\
\hline & Av & & 62.05 & 39.99 & 3.18 & 62.58 & 40.27 & 3.90 & & & \\
\hline & & & $\mathbf{L}^{*}$ & 63.84 & & $\mathbf{L}^{*}$ & 67.07 & & $I^{*}$ & 65 & \\
\hline & & 1 & $\mathbf{a}^{*}$ & 44.81 & & $\mathbf{a}^{*}$ & 35.94 & & $\mathbf{L}$ & 61.55 & \\
\hline & & & $\mathbf{b}^{*}$ & -7.21 & & $\mathbf{b}^{*}$ & -0.07 & & & & \\
\hline & & & $\mathbf{L}^{*}$ & 61.50 & & $\mathbf{L}^{*}$ & 60.37 & & a & 47.21 & \\
\hline & $\begin{array}{l}\text { Rice } \\
\text { straw }\end{array}$ & 2 & $a^{*}$ & 44.90 & & $\mathbf{a}^{*}$ & 39.79 & & $\mathbf{h}^{*}$ & 07 & d. \\
\hline 3 & & & $\mathbf{b}^{*}$ & -3.95 & & $\mathbf{b}^{*}$ & 1.51 & & b & -0.91 & p. \\
\hline & & & $\mathbf{L}^{*}$ & 57.35 & & $\mathbf{L}^{*}$ & 60.47 & & & & $\mathrm{p}$ \\
\hline & & 3 & $\mathbf{a}^{*}$ & 45.71 & & $a^{*}$ & 41.2 & & & & \\
\hline & & & $\mathbf{b}^{*}$ & -3.94 & & $\mathbf{b}^{*}$ & 0.52 & & & & \\
\hline & & & $\mathbf{L}^{*}$ & $a^{*}$ & $\mathbf{b}^{*}$ & $\mathbf{L}^{*}$ & $a^{*}$ & $\mathbf{b}^{*}$ & & & \\
\hline & Av & & 60.90 & 45.14 & -5.03 & 62.64 & 38.98 & 0.65 & & & \\
\hline
\end{tabular}

$\mathrm{CN}$, color name; d.p.p., deep purplish pink

but there was a decided difference in color sense as there was the value of blue and yellow by $b^{*}$ value out of the range of lightness $\left(\mathrm{L}^{*}\right)$ and chroma $\left(\mathrm{a}^{*} \mathrm{~b}^{*}\right)$, which is judged that solution closer to the color of azalea is deionized water.

Although bean pod ash has a color similar to deep purplish pink $\left(\mathrm{L}^{*} 61.55, \mathrm{a}^{*} 47.21, \mathrm{~b}^{*}-0.97\right)$, it color value of 2 kinds of dyeing solution water differed from the standard color. As for natural bedrock water $\left(1: 50,100^{\circ} \mathrm{C}, \mathrm{pH} 13.18\right)$, it became brighter than deep purplish pink as the value of lightness, the value of $\mathrm{L}^{*}$ out of the values of $\mathrm{L}^{*} 60.05$, a 
39.99 and $b^{*} 3.18$ increased by 0.50 , which can be seen by naked eyes, and a light color was shown as red in a value decreased by 7.22 , whereas sharpness lowered due to increase in the value of yellow of $b^{*}$ by 4.87 . With numerical values of $\mathrm{L}^{*} 62.58, \mathrm{a}^{*} 40.27$ and $\mathrm{b}^{*} 3.90$, deionized water differed by $L^{*} 1.03, a^{*}-6.94$ and $b^{*} 4.87$ as compared to the values of deep purplish pink. This study confirmed that it became brighter as the value of lightness $\left(\mathrm{L}^{*}\right)$ increased than deep purplish pink, but sharpness of color lowered as red which is the $a^{*}$ decreased and yellow increased in $b^{*}$ value. The reason for decrease in red of $a^{*}$ value and increase in yellow of $b^{*}$ value in 2 kinds of dyeing solution water is because dyeability of carthamin lowered.

Although rice straw ash showed a color sense similar to the value of deep purplish pink same as bean pod ash, color values of $\mathrm{L}^{*} \mathrm{a}^{*} \mathrm{~b}^{*}$ of 2 kinds of dyeing solution water was in the color range same as deep purplish pink rather than that of bean pod ash color. With numerical values of $\mathrm{L}^{*} 60.90$, $a^{*} 45.14$ and $b^{*}-5.03$, natural bedrock water $\left(1: 10,90^{\circ} \mathrm{C}\right.$, $\mathrm{pH}$ 10.80) became dark as lightness, the value of $\mathrm{L}^{*}$ decreased by 0.65 as compared to deep purplish pink, and $\mathrm{a}^{*}$ value decreased to 2.07 and blue increased by -1.62 in $\mathrm{b}^{*}$ value, but dyeability of carthamin was heightened as chroma $\left(a^{*} b^{*}\right)$ was the closest to deep purplish pink, and it is judged that the reason for increase in blue is because of increase in color sense by the influence of metal ions contained in natural bedrock water. Deionized water $\left(1: 100,100^{\circ} \mathrm{C}, \mathrm{pH} 10.92\right)$ differed by $\mathrm{L}^{*} 1.09, \mathrm{a}^{*}-8.23, \mathrm{~b}^{*} 1.62$ from deep purplish pink as $\mathrm{L}^{*} 62.64, \mathrm{a}^{*} 38.98$ and $\mathrm{b}^{*} 0.65$. It is considered that sharpness lowered as red which is the value of $a^{*}$ out of chromaticness indices $\left(\mathrm{a}^{*}, \mathrm{~b}^{*}\right)$ decreased by 8.23 , and the reason why natural bedrock water developed a color closer to deep purplish pink than deionized water is because dyeability of carthamin was heightened by the influence of dyeing solution water.

As a result of examining ash materials through the spectrophotometer analysis, goosefoot ash material made of deionized water has dyeability of carthamin, and it was in the range of color similar to the KS Standard azalea color, and it was confirmed that red in a value decreased to 4.25 , but a clear and deep color sense was expressed due to high lightness $\left(\mathrm{L}^{*}\right)$ and chroma $\left(\mathrm{a}^{*} \mathrm{~b}^{*}\right)$ comparing to other ash materials. Bean pod ash and rice straw ash are in the color range similar to deep purplish pink of KS Standard, but rice straw ash showed the most similar color sense despite it has low red in $a^{*}$ value as 2.00 . As a result of examining chanes in color difference of 3 kinds of ash material, there was a difference safflower color in each ash material as the range of safflower color expanded.

\subsubsection{Results of image processing software}

This study compared average value of lightness $\left(\mathrm{L}^{*}\right)$ and chromaticness indices $\left(a^{*}, b^{*}\right)$ generated as a result of color difference analysis on the $1^{\text {st }} \sim 3^{\text {rd }}$ dyed fabrics by ash materials with $\mathrm{KS}$ standard colors, and shown color change in the Table 4.

Although goosefoot ash is in the color range similar to vivid purplish red $\left(\mathrm{L}^{*} 51.37, \mathrm{a}^{*} 61.85, \mathrm{~b}^{*} 1.28\right)$, but color value of 2 types of dyeing solution water differed from the standard color. With $\mathrm{L}^{*} 52.54, \mathrm{a}^{*} 62.63, \mathrm{~b}^{*} 0.24$, natural bedrock water $\left(1: 100,70^{\circ} \mathrm{C}, \mathrm{pH} 11.53\right)$ differed $\mathrm{L}^{*} 1.17$, $a^{*} 0.78, b^{*}-1.04$ as compared with vivid purplish red, red increased in lightness and chromaticness indices $\mathrm{a}^{*}$, whereas sharpness of $b^{*}$ was heightened due to increase in blue but became murky as blue color increased. Values of deionized water $\left(1: 100,70^{\circ} \mathrm{C}, \mathrm{pH} 11.87\right)$ were measured as $\mathrm{L}^{*} 48.59$, $\mathrm{a}^{*} 62.63$ and $\mathrm{b}^{*} 0.24$, and was dark comparing to vivid purplish red as the value of lightness $\left(\mathrm{L}^{*}\right)$ decreased by -2.78 , and although sharpness was heightened due to increase in $a^{*}$ $0.86, b^{*} 2.66$ of chroma, it differed from standard color as yellow was developed higher than that of natural bedrock water.

Color value of 2 kinds of dyeing solution water made of bean pod ash is in the range of color similar to deep purplish pink $\left(\mathrm{L}^{*} 61.55, \mathrm{a}^{*} 47.21, \mathrm{~b}^{*}-0.97\right)$, and natural bedrock water (1 : $\left.100,80^{\circ} \mathrm{C}, \mathrm{pH} 12.21\right)$ differed from deep purplish pink by $\mathrm{L}^{*} 2.20$, $a^{*} 1.60$ and $b^{*} 5.80$ with numerical values of $L^{*} 63.75$, $a^{*}$ 48.81 and $b^{*} 4.83$. The color became brighter and sharpness was also heightened due to increase in $\mathrm{L}^{*} \mathrm{a}^{*}$ value, but lightness became bright as yellow increased in $b^{*}$ value. As for deionized water $\left(1: 50,100^{\circ} \mathrm{C}, \mathrm{pH} 13.22\right)$, lightness became brighter than deep purplish pink as values increased by $L^{*} 3.93, a^{*} 1.92$ and $b^{*} 7.17$ with values of $L^{*} 65.48$, a 49.13 and $b^{*} 6.20$, lightness became brighter, and red and yellow increased in chroma, and it was confirmed that deionized water is closer to deep purplish pink than natural bedrock water. 
Table 4. Comparison of $\mathrm{L}^{*} \mathrm{a}^{*} \mathrm{~b}^{*}$ values according to the ash component KS Standard (image processing software)

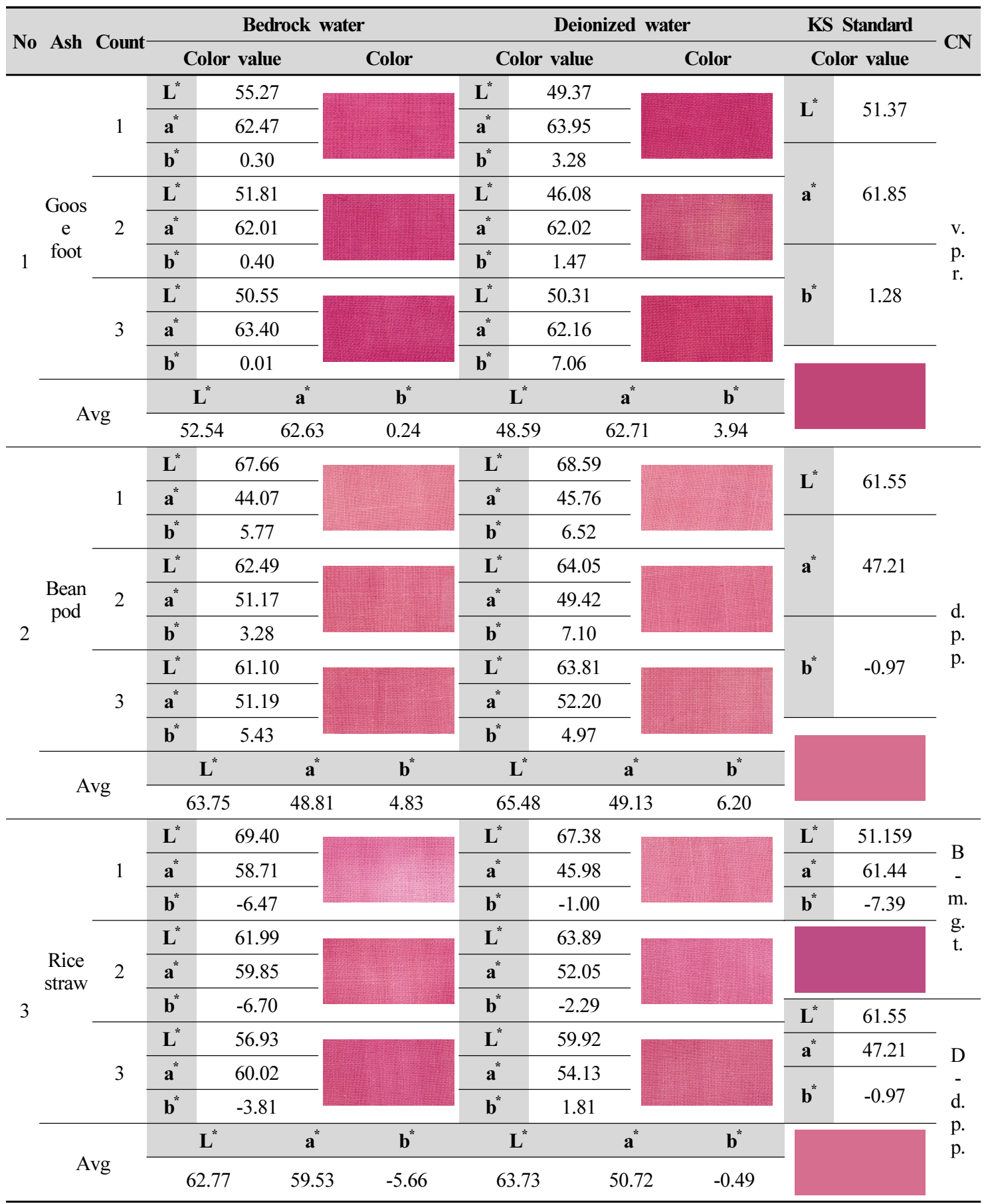

$\mathrm{CN}$, Color name; v.p.r., vivid purplish red; d.p.p., deep purplish pink; N-m.g.t., natural bedrock water - magenta; D-d.p.p., deionized water-deep purplish pink 
As for rice straw ash material, 2 kinds of dyeing solution water color value showed a significant difference in numerical values, which differs from the KS Standard Color, and natural bedrock water $\left(1: 100,60^{\circ} \mathrm{C}, \mathrm{pH} 10.98\right)$ showed a color sense similar to magenta $\left(\mathrm{L}^{*} 51.159, \mathrm{a}^{*} 61.44, \mathrm{~b}^{*}\right.$-7.39) and color sense of deionized water $\left(1: 10,70^{\circ} \mathrm{C}, \mathrm{pH} 11.43\right)$ was similar to deep purplish pink $\left(\mathrm{L}^{*} 61.55, \mathrm{a}^{*} 47.21, \mathrm{~b}^{*}\right.$ -0.97). With numerical values of $\mathrm{L}^{*} 62.77, \mathrm{a}^{*} 59.53$ and $\mathrm{b}^{*}$ -5.66 , lightness, the value of $\mathrm{L}^{*}$ became brighter as the value of natural bedrock water increased by 11.61 , and lightness became bright and chroma was sharpened as the values of $a^{*} b^{*}$ of chroma decreased to 1.91 and 1.73 . With numerical values of $\mathrm{L}^{*} 63.73, \mathrm{a}^{*} 50.72$ and $\mathrm{b}^{*}-0.49$, lightness of deionized water became brighter than deep purplish pink due to increase in $\mathrm{L}^{*}$ value by 2.18 , and chroma was sharpened as the values of $\mathrm{a}^{*}$ increased by 3.51 and $\mathrm{b}^{*}$ decreased to 0.48 . It is judged that a decided difference in color sense between natural bedrock water and deionized water가 color sense is because of the influence of metal ions contained in water.

As a result of analysis using image processing software, goosefoot ash manufactured with natural bedrock water showed the highest carthamin dyeability, which is similar to the vivid purplish red of KS Standard, and it looks dark comparing to other ash materials as the value of lightness
$\left(\mathrm{L}^{*}\right)$ decreased by $10 \sim 11$, but showed clear and deep color sense as red in a* value of chroma increased by $3 \sim 14$. Deep purplish pink was expressed in bean pod ash and rice straw ash, but rice straw ash manufactured with deionized water show the most similar color sense. And rice straw ash manufactured with natural bedrock water showed a color sense of magenta, expanding the range of safflower color and showing difference in safflower color by ash materials.

\subsubsection{Analysis and consideration of color difference}

As a result of the analysis on the color difference by ash materials, the order of ass materials that $a^{*}$ which is the value of chroma increased was goosefoot ash $>$ rice straw ash $>$ bean pod ash. As for goosefoot ash, fabric dyed with natural bedrock water $\left(1: 100,70^{\circ} \mathrm{C}, \mathrm{pH} 11.53\right)$ was confirmed to create a color which is similar to vivid purplish red of KS Standard, and average value of red $\mathrm{a}^{*}$ showed high level of 62 in both dyeing solutions, indicating that goosefoot ash is highly effective for dyeability of carthamin.

Bean pod ash (deionized water, $1: 50, \mathrm{pH} 13.22$ ) was confirmed to create deep purplish pink of KS standard, and it is considered that dyeability lowered as the value of red $a^{*}$ was 48 49 comparing to other ash materials by the influence of $\mathrm{pH}$ level. Rice straw ash (natural bedrock water,

Table 5. Safflower color analysis result of 1 to 3 staining average spectrophotometer and image processing software

\begin{tabular}{|c|c|c|c|c|c|c|c|c|c|c|}
\hline \multirow{2}{*}{ No } & \multirow{2}{*}{ Ash } & \multirow{2}{*}{\multicolumn{2}{|c|}{ Name }} & \multirow{2}{*}{ c.v } & \multirow{2}{*}{$\begin{array}{c}\text { KS } \\
\text { (1) }\end{array}$} & \multirow{2}{*}{$\begin{array}{c}\text { KS } \\
\text { (2) }\end{array}$} & \multicolumn{2}{|c|}{ Spectrophotometer } & \multicolumn{2}{|c|}{ Image processing software } \\
\hline & & & & & & & N.B.W & D.W & N.B.W & D.W \\
\hline \multirow[b]{3}{*}{1} & \multirow{3}{*}{$\begin{array}{c}\text { Goose } \\
\text { foot }\end{array}$} & \multirow{3}{*}{$\begin{array}{c}\text { (1) } \\
\text { azalea }\end{array}$} & \multirow{3}{*}{$\begin{array}{l}\text { (2) } \\
\text { v. } \\
\text { p. }\end{array}$} & $\mathrm{L}^{*}$ & 51.39 & 51.37 & 55.65 & 51.50 & 52.54 & 48.59 \\
\hline & & & & $a^{*}$ & 54.15 & 61.85 & 48.71 & 49.90 & 62.63 & 62.71 \\
\hline & & & & $b^{*}$ & 1.53 & 1.28 & -2.48 & 2.33 & 0.24 & 3.94 \\
\hline \multirow[b]{3}{*}{2} & \multirow{3}{*}{$\begin{array}{c}\text { Bean } \\
\text { pod }\end{array}$} & \multirow{3}{*}{\multicolumn{2}{|c|}{$\begin{array}{l}\text { d. } \\
\text { p. } \\
\text { p. }\end{array}$}} & $\mathrm{L}^{*}$ & \multicolumn{2}{|c|}{61.55} & 62.05 & 62.58 & 63.75 & 65.48 \\
\hline & & & & $a^{*}$ & \multicolumn{2}{|c|}{47.21} & 39.99 & 40.27 & 48.81 & 49.13 \\
\hline & & & & $b^{*}$ & \multicolumn{2}{|c|}{-0.97} & 3.18 & 3.90 & 4.83 & 6.20 \\
\hline \multirow{4}{*}{3} & \multirow{4}{*}{$\begin{array}{l}\text { Rice } \\
\text { straw }\end{array}$} & \multirow{4}{*}{\multicolumn{2}{|c|}{$\begin{array}{cc}\text { (1) } & \text { (2) } . \\
\text { d. } & \text { g. } \\
\text { p. } & \text { t. } \\
\text { p. } & \end{array}$}} & $\mathrm{L}^{*}$ & 61.55 & 51.159 & 60.90 & 62.64 & 62.77 & 63.73 \\
\hline & & & & $a^{*}$ & 47.21 & 61.44 & 45.14 & 38.98 & 59.53 & 50.72 \\
\hline & & & & $b^{*}$ & -0.97 & -7.39 & -5.03 & 0.65 & -5.66 & -0.49 \\
\hline & & & & & & & & & & \\
\hline
\end{tabular}

v.p.r., vivid purplish red; d.p.p., deep purplish pink; m.g.t., magenta; N.B.W, natural bedrock water; D.W. deionized water 
$\left.1: 50,60^{\circ} \mathrm{C}, \mathrm{pH} 10.98\right)$ was confirmed to create a color which is similar to magenta of $\mathrm{KS}$ standard, but the value $\mathrm{a}^{*}$ decreased by 8.81 in deionized water as compared to bedrock water showing the greatest difference in color, which shows that the color of dyed carthamin differs by temperature, dyeing solution water and the ratio of dyeing solution by natural ash materials.

Table 5 shows safflower color realized with safflower, and this study aimed to expand color range of ash materials and find ash that extraction of carthamin is high, so this study was able to confirm that color range of safflower color was expanded when comparing colors through the analysis using spectrophotometer and image processing software. As a result of goosefoot ash material that extraction of carthamin was the highest, spectrophotometer showed a value close to azalea color, whereas the value of image processing software was similar to vivid purplish red. Of the chromaticness indices $\left(a^{*}, b^{*}\right)$ of the two colors, $a^{*}$ value was 62.63 in image processing software and 48.71 in spectrophotometer respectively, showing about $30 \%$ of difference in color value, so it was confirmed that there was a color change even in the same fabrics dyed with safflower color, so it is judged that an analysis method suited to the characteristics of specimen needs to be applied.

Based on the above, it is possible to confirm that image processing software that analyzes color of the entire side of dyeing of fabric expanded color range than point $(3 \mathrm{~mm}$ in diameter) analysis method of spectrophotometer, so it is expected to heighten accuracy for color analysis if color analysis of the entire side and point color analysis method are used diversely.

\section{CONCLUSIONS}

This study derived a method for realizing unique safflower color based on the ash material of safflower recorded in the literature, drawing conclusions as follows.

First, as for the unique carthamin, this study confirmed that color development of red increased at $\mathrm{pH} 11.53$ which is goosefoot ash material. This study was able to identify $\mathrm{pH}$ point of time for expression of unique color through a scientific research of natural materials, and as for unique safflower color, safflower color was deepened as the value of lightness $\left(\mathrm{L}^{*}\right)$ decreased, and color became clear with increase in the value of chroma $\left(\mathrm{a}^{*} \mathrm{~b}^{*}\right)$, so this study was able to secure standard data of ash as dark and clear safflower color was realized.

Second, as for the optimum lye concentration, safflower color was the clearest after dyeing with mixture of goosefoot ash material and natural bedrock water. This study improved convenience by quantifying mixture ratio which is a part of dyeing technology.

Third, metal content of lye is estimated to be increased through the optimal temperature of goosefoot lye that red was revealed the most. Standard value of red $\mathrm{a}^{*}$ of dyeing by temperature was classified by the temperature and dyeing solution water that metal ingredient of ash material was extracted, and is judged that a variety of safflower colors were shown by ion bond activity of mineral in natural bedrock water and metal ingredient of ash material according to temperature.

Fourth, this study confirmed that $\mathrm{K}$ and $\mathrm{Si}$ out of metal ingredients in ash materials are the elements affecting carthamin. K, an alkaline ion show the most element content in goosefoot ash material, and rice straw ash material is assumed to heighten dyeability of carthamin as carthamon of safflower as $\mathrm{Si}$ is influenced rather than $\mathrm{K}$, and $\mathrm{K}$, Si that are metal ingredients are estimated to play an important role in realizing safflower color.

Fifth, when realizing safflower color of safflower using natural ash materials recorded in the literature, this study confirmed that ash material that $\mathrm{a}^{*}$ value moved to the direction of red was goosefoot ash material which was similar to vivid purplish red. When judging based on the KS standard color of each ash material, bean pod, rice straw and goosefoot can express safflower color with deep purplish pink, magenta and vivid purplish red respectively, and ash material that $\mathrm{a}^{*}$ value moved the most to the direction of red out of chroma $\left(a^{*} b^{*}\right)$ of safflower was goosefoot ash material, which is considered the most convenient to extract carthamin.

Ash material that realized safflower color of safflower through the materials recorded in the literature suggested a quantized form of dyeing method, which served as a momentum for achieving standardization of safflower color by ash materials. 


\section{ACKNOWLEDGEMENTS}

This study was conducted as part of a thesis for a doctorate at Hanseo University in 2020 and we express our gratitude.

\section{REFERENCES}

Chu, Y.J. and Nam, S.W., 1997, A study on the natural mordants in natural dyeing ( I ). Journal of the Korean Society of Dyers and Finishers, 9 (6), 33-41. (in Korean with English abstract)

Lee, M.Y. and Wi, K.C., 2019, Studies on the dyeing of safflower through the ash materials in the literature. The Korean Society of Culture and Convergence, 41 (4), 401-422. (in Korean with English abstract)

Kim, G.Y., 2010, Korea Traditional natural red-dyeing of Research. Donggok University, Seoul.

Kiyoshi, A., 1973, Gromwell dye and safflower dye. Dyeing and Textile Finishing, 21 (7), 412-423. (in Japanese)
Lee, M.Y., 2020, A study on the changes in safflower color by natural alkaline solvent. Hanseo University, Seosan.

Nam, S.W., Chung, I.M. and Kim, I.H., 1995, Dyeing of cotton fabric with natural Dye (I) - Safflower -. Textile Coloration and Finishing, 7 (2), 47-54. (in Korean with English abstract)

Park M.S. and Hong I.K., 2002, Analysis of color difference by mixed solvent composition in natural dyes extraction process. Journal of Korean Industrial Engineering Chemistry, 13 (8), 844-851. (in Korean with English abstract)

Son, K.H., Shin, Y.S., Yoo, D.I., Choi, H. and Cho, A.R., 2008, Effect of extraction solvents on color of the dyed fabrics with safflower red colorants. Journal of the Korean Society of Clothing and Textiles, 32 (3), 486-493. (in Korean with English abstract)

Tamako, O. and Mitsuhiko, H., 2007, The pH dependence of absorption spectra of carthamin aqueous solution. Sen'i Gakkaish, 63 (8), 185-192. (in Japanese with English abstract) 